\title{
18th Annual Report on the Activities of the Geneva Association
}

\author{
for the period from June 1, 1990 to May 31, 1991
}

\section{Introduction:}

The Geneva Association was founded in 1973, i. e. 18 years ago. The stated aims of the founding fathers were to make an original contribution to the progress of insurance by objective studics on the interdependence between economics and insurance. The first result of this activity was to stimulate a fundamental change in the way insurance is thought about in society, by altering the perception of its economic and social significance.

The activity started with an initial support of 24 chief executives of the most important insurance companies in Europe. Last year, membership passed the number of seventy. And after having expanded its geographical spread during the ' 70 s into the United States and Canada, the Geneva Association wclcomed a few ycars ago its first membcr from Latin America. In this 18 th year of activity, another important step forward has taken place in tcrms of membership: A first member in Japan and Australia was proposed and confirmed by the members of the Assembly. After having started as an exclusively European organization, the Geneva Association has now confirmed and reinforced its international image.

This slow but constant extcnsion at the international level is called the WIN (world insurance) programme. The number of our research activities, of the seminars we organize and in particular the number and type of our publications have considerably increased during this period of 18 years. Throughout this process have been followed rigorous management principles:

- The Geneva Association, whilst probably the most prestigious insurance organization in the world in terms of its membership, has a key role to promote new ideas (if possible "two or three years too early"), to propose a new image of insurance and to create solid bridges between the professions within the various sectors of the economy, the universities and research centres, the international organizations which in one way or another are concerned in the management of risk. Quality and credibility are the essential asset we have to build up in our reserves in developing such activities.

Given the nature of our activities, the Geneva Association had to remain small and only start new initiatives when the old ones could continue to develop by their own inertia. In terms of cost control, the following key references can be kept in mind: Our total budget is today, in real terms only about $15 \%$ higher than it was during the first year; the membership fee paid by each company is today, in real terms, $43 \%$ of that paid during the first year 
by the founding members; our office space in Geneva has expanded from $55 \mathrm{~m}^{2}$ in 1973 to $130 \mathrm{~m}^{2}$ today. There is still only one person remunerated full time, but we have today three part-time secretaries against only one part-time secretary in 1973. In addition, there is an assistant secretary general working 2 days per weck on a regular basis. All other contributors are paid ad hoc for specific activities, research programmes or organizational contributions.

- One of the key consequences of doing work of essentially promotional nature is that in many fields, we can say that we have done something successful only at the moment when our initiative is taken over on a larger scale by somehody else. 16 years ago, we made the first overall study in Europe of Risk management practices in industry. We did then the first study on Computer risks, the first studies in several European countries on The limits of social security and the complementary role of life insurance. We were fortunate enough to hit several consistent targets, where our success is demonstrated by the fact that they have later been developed either by insurance companies, by larger marketing organizations or other institutions.

But the key to all this programme was the initial intuition that the problem of managing risk and insurance in the contemporary economy was entering a new historical phase, changing considerably the reality as well as the perception of the economic role of insurance in today's world.

\section{The importance of insurance in the economy and its image}

\subsection{Insurance business as a typical example of a service activity}

- At the occasion of our lectures, seminars and publications, we have pursued our research programme based on the concept that the modern economy is an economy where service functions and activities are the most important ones in the utilization of resources and in the creation of wealth. The notion of the service economy concerns not only the services sector but is founded on the fact that within the modern, and in particular the most advanced technological manufacturing sector, service activities are dominant.

We also stress the fact that services are not in opposition to or in contradiction with the manufacturing sector but, quite to the contrary are an integral part of a more advanced level of the industrialization process. Similarly, the development of the manufacturing sector 200 years ago at the starting of the industrial revolution, was increasing the overall economic productivity, including that of agriculture.

It is clear that once the concept of a service economy as the basis of an advanced contemporary cconomy is accepted, the example of insurance and the way in which it functions becomes much more relevant. In the old traditional economic philosophy based on the priority of simple manufacturing systems, insurance was a secondary, albeit important, type of activity. In the service economy, where performance and the management of risk and uncertainty become an essential ingredient of all management functions, insurance takes the role of an interesting and obvious example for other economic activities. This concerns both the development of new ideas among economists as well as management practice. In other words, this fucls a process of constant upgrading of the image of insurance.

- We have stimulated this process first through our PROGRES (programme de recherche sur l'ćconomie de service) research programme. Over the last seven years, we have organized 
a seminar on this subject every year. The first six took place in Geneva and the last one in Paris at the Ecole des Arts et Métiers on May 13-15, 1991. PROGRES traditionally extends the notion and the discussion on the new service economy not only in Western Europe and the United States but in Eastern Europe as well. The organization of these seminars is backed by the PROGRES newslctter, issucd twice a year, which has been the first in Europe to provide a coordination and information service among those interested in the service economy.

- In addition to the more academic PROGRES seminars, we have contributed since 1990 to the organization of an international forum on the scrvice economy with reference to the negotiations of the Uruguay Round concerning the liberalization of trade in services at GATT in Gencva. For this initiative we have cstablished a collaboration with professionals and research groups in various scrvice scctors such as telecommunications and professional services. In this way, we bring together representatives of the negotiating parties at GATT, service companies as well as representatives of industrial groups in order to mect cach other and confront thcir vicws on issues relatcd to servicc activities. During the first forum last year, the insurance scctor was represented by the secretary general of the Comité Européen des Assurance, Mr. Francis Lohéac, by Mr. Ruy de Carvalho, Board Member of the Geneva Association as well as by Mr. John Greig of Lloyd's. The procecdings of this highly successful forum arc now availablc.

The second forum has and taken place on May 21 and 22, with an introduction by Sir Brian Corby, President of the Geneva Association. After a first day of general prescntation and discussion on the scrvices issues at stakc at the Gatt negotiations, the second day was devoted to three workshops: one dedicated to insurance and banking, organized directly by the Geneva Association, another to telecommunications with ITU (International Telecommunication Union), and a third onc on professional services, organized with the collaboration of the British Coalition for Services.

- All the studies and meetings related to the liberalization of services in the world are reported in the PROGRES newslctter, of which No. 13 and 14 have been issued during this period of activity. In addition, Orio Giarini and Walter Stahel have published the French version of their book "The Limits to Certainty - The basis of the service economy" by the Presses Polytechniques et Universitaircs Romandes, Lausanne, in June 1990. The original English version, published by Kluwer two years ago, is now in reprint. An updating of this version is being prepared with the inclusion of a new chaptcr on "The Four Pillars: A social policy for the service cconomy".

\subsection{World issues and strategies concerning insurance development}

- Four years ago we have inaugurated the "Geneva Lectures" series, where members of the Geneva Association are given the opportunity to present their views on key issues in a country other than their country of origin. In the Geneva Papers No. 57 we have published the "Geneva lectures" given by three of our members (Mr. Bébéar, Mr. Randone, Prof. Farny) in Ncw York, Brussels and Madrid.

The fifth Geneva Lecture was given by Prof. Reimer Schmidt in Holland on November 15,1990 at the Zeist Castle near Utrecht, on the subject of German reunification and insurance. This lecture was introduced by Mr. Bartelds, Chairman of N. V. AMEV, and was organized with the collaboration of the Munich Reinsurance Co. 
- The sixth Geneva Lecture is presented at this General Assembly of the Geneva Association by Mr. Maurice Greenberg; the seventh Geneva Lecture will be given by Mr. Ruy de Carvalho in Athens on October 3rd, 1991. We are benefitting here again of the direct collaboration of the Munich Reinsurance Co. which provides the logistics for this initiative.

- A clear indication of the greater relevance of insurance activities in the world has been provided in the last years by the fact that some sort of insurance activity or research is now bcing conducted in practically all the major international organizations in the world. One of the latest examples is the foundation of MIGA, the Insurance Guarantee Agency of the World Bank, whose representative is with us at this General Assembly.

In order to present an analysis of this trend, we are preparing a special issue of the Geneva Papers whcre the insurance related activities of the most important international organizations will be prescnted such as: the European Communities, the OECD, the Agency for Atomic Encrgy, the MIGA, the World Maritime Organization, the GATT, UNCTAD, UNDRO, UNIDO, ctc.

\subsection{The european scene}

- Ten ycars ago the Geneva Association had awarded a scholarship to Mr. Christian Grosjean, in order to study the legal and economic implications of European intcgration as related to insurance. Since then, Mr. Grosjean has become a confirmcd lawyer and has continued to dcvclop his study, which in the last few years, has benefitted from the experience and collaboration of Mr. Rogcr Mcrkclbach.

- This has resulted in a final report of 700 pages which is the most complete document available today on "Private Insurance in the European Communities", with considerable attention given to the agrecment between the European Communities and Switzerland. This study was published in four volumes in the series "Etudes \& Dossiers", bearing the number 149 to 152 for the period of November 1990 to February 1991. At this stage, the document is only available in French, but contacts have been made in order to stimulate the production of an English version in collaboration with the international organizations interested in this matter.

- The evaluation of the developments of the European monetary systcm and the utilization of ECU has been persued and threc new articles on this subject werc published in the Geneva Papers No. 57 (October 1990).

- Concerning the new developments in Eastern Europe, a special session was organized in Vienna on September 17 with original contributions of experts from six East Europcan countries. A considerable contribution to this event was made also by economists and insurance companies in Austria and Germany. All the texts presented in Vienna were published in "Etudes \& Dossiers No. 147" (September 1990) and a selection of papers in the Geneva Papers No. 58 (January 1991).

\section{Specific research activities related to the life and to the non-life sector}

\subsection{The life sector (the Four Pillar strategy problems)}

- In October 1990, we have published the Bulletin No. 9 on the activities related to the Four Pillars. The editor of this bulletin, Madame Geneviève Reday-Mulvey who now works 
from London, has already been invited several times to contribute to international meetings discussing this subject. In addition, Prof. Denis Kessler and Orio Giarini have also delivered about half a dozen lectures on this subject over the period considered.

- An extension of the research program to evaluate the consequences of demographic trends on pensions and employment as well as on life insurance has been conducted by Mr. Amin Rayan and Mrs Genevieve Reday-Mulvey. The results are presented at this General Assembly at the session on Tuesday morning.

\subsection{Research programme in the non-life sector}

- In the Geneva Papers No. 56, we have published the final version coordinated by W. Pfennigstorf on "Comparative Procedures in Liability and Compensation". On the basis of this report, a new programme has started with the contribution of insurance experts in several countrics. A second intermediary report will be presented at the fourth International Conference on Strategic Issues for Insurance which we are organizing in London from October 28-30, 1991.

- Following the tradition of our studics on risk management problems in specific industrial sectors, we have started a preliminary analysis of the catering industry in Great Britain and France taking into consideration the experiences in Germany and other European countries as well. The catering market (food service in USA terms) is made up of about 25 sub-sectors which are grouped into three main categories: institutional (schools, hospitals, clinics, old people homes, prisons, armed forces), office/factory (catering for office/factory employees), commercial catering (individual or chain restaurants, hotels, restaurants). The catering industry has gathered in Europe a tremendous momentum and the basic objective of the study is to establish the liabilities to which the caterer is exposed to from both consumcrs and cmployces, as well as the forcsccable changes and the implications for the insurance industry.

- Study on "Crime and Insurance": this study is now finished and the original German version has been revised by Prof. Reimer Schmidt. An English version was also prepared under his supervision and was distributed in our series "Etudes \& Dossiers" No. 154 in April this year. The questionnaire prepared for this research in German is now distributed in English for a next step of the study in other countries.

\section{Other research programmes}

4.1. The economic hasis of competition, economy of scale and efficiency of insurance companies

- Prof. Denis Kessler, who has managed the research programme in this sector for the Geneva Association, has edited the results of his effort in the issues Nos 59 and 60 of the Geneva Papers (April and July 1991). The Geneva Papers No. 59 has also included the 13th Annual Lecture of the Geneva Association given by Prof. William Baumol on June 10, 1990 in Brussels.

\subsection{ASIR (Advanced Simulation of Insurance and Reinsurance) and information networks \\ - The original model of the Geneva Association, ASIR, is still being used for research purposes at the University of Toulouse.}


- We have also organized on November 19 and 20 in Geneva, a first seminar on telecommunication networks for insurance. At this occasion, the major representatives of various insurance networks, such as RINET, ASSURNET, RITA, the German and the British Networks as well as representatives of the European Communities and of CAPA, have discussed the future collaboration possibilities at the international level. A document containing the presentation at this seminar was prepared and distributed in the "Etudes \& Dossiers" series (No. 155/ May 1991).

4.3. As a consequence of the meeting of November $19 / 20$, we have organized an enquiry on international electronic communications for insurance and its perspectives. A questionnaire was prepared with the collaboration of four of our members and distributed to the correspondents of the Geneva Association as well as to outside companies and brokers. The results of this enquiry will be presented in London during the Strategic Issues Conference on October 28-30.

\section{The promotion of risk and insurance economics for economists, lawyers and engineers}

\subsection{Programines for the economists:}

- The Annual Lectures of the Geneva Association have been devoted, for the last 15 years, to present and discuss risk and insurance related issues with world reknown economists from Kenneth Arrow to Martin Feldstein, from Joseph Stiglitz to William Baumol. The 15th Annual Lecture in this series was organized at the occasion of this General Assembly in the morning of Tuesday, June 11 and given by Prof. Tony Atkinson of the London School of Economics on "The Future of Social Insurance". This lecture was commented by Prof. Denis Kessler, Mr. John Flemming, Chief Economist of the European Bank for Reconstruction and Development, London, Prof. Pierre Pestieau of the University of Liège/Belgium and Prof. Agnar Sandmo of the Norwegian School of Economics and Business Administration.

- The 17th Annual Seminar of the European Group of Risk and Insurance Economists took place in Vienna on September 18th and 19th. At this occasion, Prof. Elmar Helten has delivered the 2nd Geneva Risk Economics Lecture on the links between theory and practice in insurance. In addition, one day was devoted to the analysis of insurance development in Eastern Europe; the papers presented on this issue were published in the Geneva Papers No. 58 (January 1991). The programme of an update of the study of "The teaching of risk and insurance economics in European universities" is still underway at the City University Business School. In addition a new study concerning the same subject for Eastern Europe has started at the University of Cologne under the supervision of Prof. Dieter Farny and should be available in the coming months.

During this period, No. 26 and 27 of the Newsletter of the European Group of Risk and Insurance Economists were issued, containing additional information on our activities in this sector. It is worth knowing that we are entering a new phase in which new teaching opportunities and posts of risk and insurance economics are being created in many countries at an accelerated rate.

\subsection{The programme for engineers on risk management and industrial risks}

- The teaching of risk and insurance economics for engineers is a survey that we have already done in the past for Germany, the Scandinavian countries and Holland. An ex- 
tension of this study has started in Italy (with the contribution of the ltalian Institute for Insurance Education, IFA) and in Madrid (with the collaboration of UNESPA).

- The Geneva Association has contributcd to a scrics of conferences and lecturcs which are described in the Risk Management Bulletin No. 9 and 10, published under the responsibility of Walter Stahel. The eighth seminar of MORE (Management of Risk and Engineering) is under preparation as well as two new seminars on risk and society, of which one is organized with the collaboration of the International Scicnce Policy Foundation, London and of the Intcrnational Council of Scientific Unions, Paris, to be held in Bratislava on November 3-5, on the subject of "Biotechnology and risks" and the other one on "Climatic changc and their cffects on risks" (within the fourth International Conference on Strategic Issues, London, October 28-30, 1991.

\subsection{The promotion of cross fertilization between law and economics and insurance}

- We have developed a close collaboration with the European Association for Law and Economics, which has 300 members sprcad in universities and rescarch centres in several European countries. In the Geneva Papers No. 58 of January 1991, Prof. Stuart from the Lund University in Sweden, has edited four papers presented at the last joint meeting we organized in 1989 with this association. The fourth meeting has taken place in Paris in April 1991, with the collaboration of Prof. Denis Kessler, who is now President of the French Federation of Insurance Companies.

\section{Publications}

\subsection{The Geneva Papers on Risk and Insurance "Theory"}

Under the leadership of Prof. Henry Loubergé who was for many years Vice Secretary General of the Geneva Association, and of Prof. Harris Schlesinger, we have consolidated during 1990 the publication of a "Theory" series of the Geneva Papers with two issues published in April and September 1990. We have now come to an agreement with an important publisher, Kluwer, who will now publish the Geneva Papers - Risk and Insurance "Theory". This is a major accomplishment in the history of the Geneva Association in trying to upgrade the quality of risk and insurance economics; it has become feasible thanks to the contribution as associate editors of many first class economists such as Robert Merton, Steven Shavell of Harward University and Joseph Stiglitz of Stanford University, together with about 15 economists of the best world reknown universities in different countries. It is also the fruit of 15 ycars of constant activity in this area, thanks in particular to the contribution of Henry Loubergé.

\subsection{The Geneva Papers on Risk and Insurance "Issues \& Practice"}

- The creation of the "theory" series has made it possible to produce more applied papers in our traditional series of the Geneva Papers.

It is worth knowning that the number of subscriptions to this journal has almost doubled in the last year thanks to a campaign we have promoted from Geneva. We are now approaching the total number of 500 paid subscriptions and we expect from our agreement with Kluwer to become more and more efficient in this arca. We have published in the last year the following issues:

- No. 56 / July 1990

COMPARATIVE STUDIES IN LIABILITY AND COMPENSATION 
- No. 57 / October 1990 INSURANCE STRATEGIES AND ISSUES

- No. 58 / January 1991 STUDIES IN LAW AND ECONOMICS PERSPECTIVES OF INSURANCE IN CENTRAL AND EASTERN EUROPE

- No. 59/ April 1991 STUDIES ON PRODUCTIVITY IN INSURANCE

\section{3. "Etudes et Dossiers"}

We have published in this scries:

- No. 147 / September 1990 PERSPECTIVES OF INSURANCE IN EASTERN EUROPE (in English and German). Papers from the 17th Seminar of the European Group of Risk and Insurance Economists.

- No. 148 / October 1990 INSURANCE ECONOMIC ISSUES. Papers from the 17th Seminar of the European Group of Risk and Insurance Economists.

- No. 149-152/Novcmber 1990 to Fcbruary 1991 L'ASSURANCE PRIVEE DANS LA COMMUNAUTE EUROPEENNE ET L'ACCORD ENTRE LA CE ET LA SUISSE (four volumes).

- No. 153 / March 1991 RISK ANALYSIS IN OCEAN EXPLOITATION AND MANAGEMENT OF LARGE RISKS

- No. 154 / April 1991 CRIME AND INSURANCE. Analysis of the situation, eauses and influences.

- No. 155 / May 1991 ELECTRONIC DATA EXCHANGE IN INSURANCE. THE EXPERIENCES OF ASSURNET, RINET, RITA AND OTHER NETWORKS.

Papers presented at the seminar organized in Geneva on November 19-20, 1990).

\subsection{Others}

The following Ncwsletters have been issucd:

- Newsletter of the European Group of Risk and Insurance Economists, Nos. 26, 27

- Bulletin on "The Four Pillars" Nos. 8, 9, 10

- PROGRES Newsletter Nos. 13, 14

- World Fire Statistics Centre Bulletin No. 8

- Information Letters $119,120,121,122,123,124$

- Risk Management Bulletin Nos. 9, 10

7. Lectures given by the staff of the GENEVA ASSOCIATION and participation to conferences, including major publications

The Secretary General Orio Giarini has given the followings lectures:

- July 9, 1990, Paris: Moderator at the International Insurance Seminar's Confercnce. 
- July 13, San Scbastian, EUROCAPA Summer School "Assurance et le 4ème pilicr": All the lectures presented at this school have been published in a book of proceedings.

- October 29, Paris: Forum SCOR, "Les conditions économiques de l'évolution de la demandc cn responsabilitć civilc".

- November 30, London, for AXA University, "The reasons for insurance developments in the contemporary economy".

- Fcbruary 7-8, 1991: Participation to the Financial Scrviccs Forum in Davos, invitcd by the World Economic Forum.

- March 24, Paris: Lecture on "The problems of a service economy" for the strategic management tcam of Nissan automobiles.

- April 9, Stockholm: Lecture on "The service economy perspectives and problems" at the annual meeting of the Swedish Coalition of Service Industries, presided by Björn Wolrath.

- April 12, Paris: Panel discussion on "The future of reinsurance", organized by SCOR.

- May 15, Paris: "The search for quality management in insurance", organized by Progress Management Consultants.

\section{Among the publications:}

- "Liability and Compensation - The insurance and risk management point of view" in "Industrial risk management: A life cycle cngineering approach", published by Elsevier, Amsterdam 1990 (pp. 55-62).

- The same article has been published in a special issue of the Journal of Occupational Accidents, volume 134, Nos. 1 and 2, September 1990.

- "Comment gérer l'imprévisible". Interview for "Bilan", Lausanne, November 1990.

- "L'ćconomie de servicc ct la gestion du risque", published in "Futuriblcs", Paris, November 1990 (pp. 55-66).

- "Le système monétaire européen, l'écu et la Suisse", edited by Orio Giarini et Oliver Wirth, 110 pages, September 1990. Publications of the Graduate Institute of European Studies, Geneva.

- "La responsabilité civile dans la nouvelle économie de service", January 1991, SCOR Notes, pp. 18-20, Paris.

Walter Stahel, Deputy Secretary General of the Geneva Association, has contributed to the following conferences:

- September 11-12, presentation of a paper on "Interdependence of factors in disasters: risk prevention, system complexity and system design" at the University of Bradford: Sccond Annual Disaster Prevention and Limitation Conference.

- September 25-29, Berlin: High level Unesco Colloquium on Science and Technology for the future of Europe - New forms of cooperation between East and West. 
- November 3-5, Strasbourg: Council of Europe: Journées d'études sur les incidences psycho-sociologiques des grandes catastrophes, organisées par le Conseil de l'Europe ct lc Centre Européen pour la médecine des catastrophes.

- November 19-20, Gicneva: Workshop on Electronic Data Exchanges in Insurance.

- December 6, Paris: International Council of Scientific Unions, planning mecting of the Organizing Committce for the 1991 COBIOTECH East-West Conference on Biotechnology.

- January 27 to February 1, 1991, Santa Barbara, CA/USA: Presentations (with Richard Lyon, Retired VP Exxon Engineering) at the Opening Session "Point-Counterpoint", and on the "International Pancl on Global Issues" of the Engineering Foundation Conference on "Future Directions in Pollution Prevention and R \& D".

- February 26-27, Baden b/Wicn/Austria: Presentation on "Öko-Marketing" am Umweltseminar zum Thema "Industrie und Umweltschutz - Problemanalyse und Umsetzung in die betriebliche Praxis" der Vereinigung österreichischer Industrieller und der Bundeswirtschaftskammer, Wien.

- March 12-14, Berlin: Represented the Geneva Association at the "Jahrestagung des Deutschen Vereins für Versicherungswissenschaft".

- April 3-5, Paris: Introduction to the Fourth Joint Conference by the European Association on Law and Economics and the Geneva Association on "Law and Economics of Environmental Policy".

- April 6-8, Berlin: Represented the Geneva Association at the 2nd Steering Committee meeting of the planned ICSU-COBIOTECH-Geneva Association conference on Biotechnology, to be held Nov. 4-6, 1991 in Bratislava. (W. Stahel is in charge of the workshop on "Economic, social and technical repercussions of Biotechnology" for the Geneva Association (programme on Risk and Society) and ISPF Europe (Science meeting No. 4).

- May 3, London: Represented the Geneva Association at the 11th Conference on 'Risk and Society'-Programme of the Geneva Association on "Airline Insurance - Feast of Famine?" The Institute of London Underwriters.

\section{He published the following papers:}

- "Interdependence of factors in disastcrs: The rolc of natural and human factors and of technical risks"; in: Proceedings of the European Workshop at the 2nd Disaster Prevention and Limitation Conference on "Emergency Planning in the 1990s" Bradford University, September 13, 1990.

- "Risk Prevention and System Design: The Role of the Designer-Engineer and the Role of Insurance in Risk Management"; in: Forcnsic Engineering, vol. 2, Nos. 1/2, pp. 113 -117; Pergamon Press, USA.

- "Eine neue Beziehung zu den Dingen: Verkauf von Nutzen statt von Produkten" (die Strategie der Dauerhaftigkeit); in: Neue Zürcher Zeitung, Beilage Technologie und Gesellschaft, Nr. 49 vom 28. Februar 1990. 
Geneviève Reday-Mulvey, who is in charge of the documentation and research programme for the "Four Pillars", has presented the following papers:

- October 9, The Hague: At the United Nations Seminar on Personal and collective services "The Four Pillars Strategy - An opportunity for the service economy".

- April 18, 1991, Paris: At the Conference on "Life, Disability and Pensions: To-Morrow's Challenge" organised by La Caisse Nationale de Prévoyance: "Le 4ème pilier, une contribution à la prévoyance de demain".

- June 7, 1991, Pisa: At the ESPE Conference: "The lengthening of working life in the 1990's in France: favourable trends and obstacles".

She attended the first European Conference on Human Resource Strategies in Financial Services "Capital People", in London, on December 7, 1990.

\section{She published two papers:}

- "Allongement de la durée de Vie - Allongement de la durée d'activité" in an UAP-FTE publication "Incidences de l'allongement de la duré de vie sur la carrière des chefs d'entreprises", Paris, 1990.

- "Le 4ème pilier et les femmes" in the Swiss Bulletin for Women, Geneva, April 1991. 